\title{
Rola mikroRNA w patogenezie i przebiegu chorób wątroby
}

\section{The role of microRNAs in the pathogenesis and progression of liver diseases}

\author{
Sylwia Szeląg ${ }^{\bowtie}$, Mateusz Kurzawski \\ Pomorski Uniwersytet Medyczny w Szczecinie, Zakład Farmakologii Doświadczalnej i Klinicznej, al. Powstańców Wlkp. 72, 70-111 Szczecin \\ $\triangle$ sylwia.szelag@pum.edu.pl
}

\begin{abstract}
MicroRNAs are short non-coding RNAs that regulate the expression of genes at the post-transcriptional level. They play a key role in a number of biological processes, including cell differentiation, immune response, apoptosis and metabolism regulation. They are also directly or indirectly involved in the development and
\end{abstract}

\section{ABSTRAKT}

MikroRNA to krótkie niekodujące cząsteczki RNA regulujące ekspresję genów na poziomie potranskrypcyjnym. Odgrywają one istotną rolę w wielu procesach biologicznych, takich jak różnicowanie komórek, odpowiedź immunologiczna, apoptoza czy regulacja metabolizmu. Są też bezpośrednio lub pośrednio zaangażowane w rozwój i przebieg wielu schorzeń. W przypadku chorób wątroby, oprócz zmian ekspresji miR-122, swoistego dla progression of numerous diseases. In liver diseases there are many microRNAs, including miR-122, whose expression depends on the disease aetiology. Therefore, analysis of microRNA profile may have a diagnostic and prognostic value, and in the future may be useful in planning liver disease therapy.

Keywords: miRNA; liver failure; regulation of gene expression.

\section{WSTĘP}

Wątroba pełni wiele ważnych, złożonych funkcji związanych m.in. z wydzielaniem, detoksykacją, prawidłowym metabolizmem i magazynowaniem, dlatego też wszelkie zaburzenia w działaniu tego narządu mają znaczący wpływ na funkcjonowanie całego organizmu. Pomimo olbrzymiego potencjału regeneracyjnego pogorszenie czynności wątroby związane z wystąpieniem przewlekłej lub ostrej niewydolności tego narządu stanowi istotny problem kliniczny. Do przyczyn przewlekłej niewydolności wątroby należą m.in. trwające przez wiele lat wirusowe zapalenie wątroby typu B (HBV) lub wirusowe zapalenie wątroby typu C (HCV), długoletnie nadużywanie alkoholu, narażenie na działanie substancji hepatotoksycznych czy też długotrwałe stosowanie wysokokalorycznej i bogatotłuszczowej diety. Do zaburzenia funkcji wątroby może też dochodzić wskutek przewlekłego procesu zapalnego mającego podłoże autoimmunologiczne oraz schorzeń przebiegających z przewlekłą cholestazą. Z kolei główną przyczyną ostrej niewydolności są zatrucia lekami (w tym paracetamolem), a także zaostrzenia chorób wirusowych i autoimmunologicznych. W przebiegu większości chorób wątroby, szczególnie przewlekłych, dochodzi do jej stłuszczenia lub zwłóknienia, a ostatecznie do marskości narządu. Niezależnie od przyczyny uszkodzenia miąższu wątroby rozwój niewydolności jest procesem złożonym, a postępujące zmiany zachodzą nie tylko na poziomie komórkowym, ale również molekularnym.

tego narządu, obserwuje się także zmiany profilu innych miRNA, których ekspresja zależy od etiologii schorzenia. Analiza profilu mikroRNA może mieć zatem wartość diagnostyczną i prognostyczną, a także może być w przyszłości przydatna w planowaniu terapii chorób wątroby.

Słowa kluczowe: miRNA; niewydolność wątroby; regulacja ekspresji genów.
MikroRNA (miRNA) są to krótkie, jednoniciowe, zwykle ok. 22-nukleotydowe cząsteczki kwasu rybonukleinowego, które regulują ekspresję genów na poziomie potranskrypcyjnym. Swoisty efekt określonego miRNA zależy od jego sekwencji determinującej geny docelowe, których ekspresja może być przez nie regulowana. W komórkach zwierzęcych miRNA łączy się z najczęściej nie w pełni komplementarną sekwencją mRNA genu docelowego, powodując zahamowanie translacji. Początkowo szacowano liczbę ludzkich miRNA na ok. 1000, obecnie wiadomo, że jest ich znacznie więcej. MikroRNA pełnią istotną rolę $w$ wielu procesach fizjologicznych, takich jak proliferacja i różnicowanie komórek, regulacja cyklu komórkowego, odpowiedź immunologiczna czy apoptoza. Ponadto zaangażowane są w przebieg procesów patologicznych, wpływając m.in. na rozwój reakcji zapalnych czy onkogenezę [1]. Według wyników licznych badań profil ekspresji miRNA zmienia się w przebiegu różnych schorzeń nie tylko w dotkniętym chorobą narządzie, ale również w osoczu lub surowicy pacjenta, dlatego uważa się, że cząsteczki te mogą być dobrym biomarkerem wielu chorób [2].

Pomimo że marskość wątroby jest końcowym stadium wielu różnych chorób, kaskada zmian prowadzących do skrajnej niewydolności jest odmienna i zależna od przyczyny, a różnice dotyczą także poziomu molekularnego regulowanego m.in. poprzez zmiany ekspresji genów przez miRNA. Badania dotyczące zmian profilu ekspresji miRNA w wątrobie mogą zatem przyczynić się do pełniejszego wyjaśnienia patofizjologii poszczególnych schorzeń. U części chorych rozwój marskości 
przebiega bezobjawowo, a jej ostateczne potwierdzenie możliwe jest jedynie na podstawie badania histopatologicznego wycinka wątroby, co jest związane z koniecznością wykonania biopsji. Ponieważ podczas uszkodzenia komórek wątroby miRNA przedostaje się do osocza, analiza krążącego miRNA stanowi także cel badań zmierzających do określenia potencjalnych markerów, swoistych dla stanu klinicznego i etiopatogenezy choroby, co mogłoby znaleźć zastosowanie w nieinwazyjnej diagnostyce.

Celem pracy było przedstawienie w zarysie aktualnego stanu wiedzy na temat znaczenia i wpływu mikroRNA na rozwój i przebieg wybranych schorzeń wątroby prowadzących do niewydolności tego narządu.

\section{MikroRNA w zakażeniu wirusem HBV}

Zakażenie wirusem HBV może prowadzić do ostrego lub przewlekłego zapalenia wątroby typu B. Przewlekłe zapalenie rozwija się u nawet $80-90 \%$ dzieci zarażonych podczas 1. r.ż. oraz u mniej niż 5\% dorosłych. Pomimo że od 1982 r. dostępna jest szczepionka chroniąca przed zakażeniem HBV i jego konsekwencjami, szacuje się, że obecnie ok. 240 mln osób cierpi na przewlekłe zapalenie wątroby typu $\mathrm{B}$, a rocznie z powodu powikłań zakażenia umiera ponad 780 tys. osób na całym świecie. Powikłania te to przede wszystkim marskość i/lub nowotwór wątroby, które rozwijają się u 20-30\% osób z chroniczną infekcją [3].

MikroRNA w zakażeniu HBV ma dwojakie znaczenie. Z jednej strony miRNA obecne w komórkach wątroby gospodarza oddziałują z genomem wirusa i w ten sposób wpływają na jego replikację. Z drugiej strony przedostanie się wirusa do hepatocytów może modulować profil ekspresji miRNA w zakażonych komórkach. Jak udowodniono, białkiem wirusowym, które odgrywa rolę w regulacji wątrobowych miRNA, jest białko X wirusa HBV (HBx) [4]. Wpływa ono m.in. na funkcję czynnika transkrypcyjnego p53 pełniącego rolę supresora nowotworowego. Białko X hamuje antyapoptotyczną aktywność p53 poprzez tworzenie z nim kompleksu uniemożliwiającego prawidłowe działanie supresora [5]. Konsekwencją zahamowania aktywności p53 może być progresja proliferacji i brak inicjacji apoptozy związany z ryzykiem wystąpienia nowotworu wątroby w przebiegu przewlekłego zakażenia HBV. Antyapoptotyczny efekt p53 związany jest z wpływem na ekspresję miRNA, m.in. miR-34a, miR-145 i miR-192, która podlega modyfikacji w wyniku oddziaływania białka X [6]. Wymienione mikroRNA odgrywają ważną rolę m.in. w regulacji proliferacji i apoptozy, wpływając na ekspresję genów biorących udział w tych procesach. Innym czynnikiem transkrypcyjnym aktywowanym przez HBx jest NF- $\kappa B$, który pełni kluczową rolę $\mathrm{w}$ regulacji immunologicznej odpowiedzi na infekcje, a także inne czynniki, w tym stres oksydacyjny czy uszkodzenie komórki [7]. Aktywacja NF- $\kappa$ B indukuje ekspresję miR-146a, które również związane jest z reakcjami układu odpornościowego, a także wpływa na inne miRNA, w tym miR-224 [8, 9]. Białko X wirusa HBV może też obniżać ekspresję miRNA z rodziny miR-16, które pełnią rolę supresorów nowotworowych. Wzmaga to proliferację komórek wątroby i może mieć duży wpływ na przebieg przewlekłego zapalenia związanego z zakażeniem HBV [10]. Ponadto HBx zwiększa ekspresję miR-29a, co wykazano zarówno w badaniach in vitro, jak i in vivo. MikroRNA-29a bezpośrednio hamuje ekspresję genu PTEN, którego produkt białkowy spowalnia migrację komórek nowotworowych [11]. Białko X wirusa HBV ingeruje także w sam proces tworzenia dojrzałych cząsteczek miRNA, hamując aktywność białka Drosha [12]. Inne miRNA, których ekspresja zmieniana jest w obecności HBx, to m.in.: miR-21, miR-101, miR-145, miR-222 czy miRNA z rodziny let-7 [13, 14, 15].

Prawdopodobnym mechanizmem oddziaływania HBx na ekspresję większości miRNA jest powodowanie zmian epigenetycznych w postaci metylacji DNA czy modyfikacji histonów. Zmiany tego typu mają miejsce m.in. w przypadku miR-132 i miR-205, dla których obniżenie ekspresji, obserwowane w liniach komórkowych transfekowanych genem $H B x$, wynikało z hipermetylacji regionów promotorowych tych miRNA [16, 17].

Oprócz oddziaływania wirusa HBV na profil ekspresji miRNA w komórkach gospodarza występuje także zjawisko odwrotne, polegające na wspomaganiu procesu replikacji HBV przez niektóre miRNA występujące w hepatocytach. Wykazano, że miR-1, miR-15b, miRs-372 i miR-373 mogą promować replikację wirusa poprzez wpływ na aktywność czynników transkrypcyjnych istotnych dla replikacji $\operatorname{HBV}[18,19,20]$. Innym miRNA promującym replikację HBV jest miR-501. Jego celem jest mRNA dla HBXIP, czyli białka będącego inhibitorem replikacji HBV (poprzez interakcję z białkiem X). Zahamowanie ekspresji HBXIP przez miR-501 zwiększa zatem replikację wirusa [21]. Swoisty profil ekspresji miRNA w hepatocytach, obejmujący miRNA niezbędne do namnażania wirusa, może być zatem związany z jego tropizmem. Z kolei inne miRNA, m.in. miR-125a-5p, miR-199a-3p i miR-210, hamują replikację HBV poprzez wiązanie do wirusowego mRNA kodującego jego białka powierzchniowe $[22,23]$. Obserwacja ta jest zgodna z teorią, wg której pierwotną funkcją miRNA nie była regulacja procesów komórkowych, a właśnie obrona przed wirusami. Badania wskazują, że oprócz bezpośredniego wiązania z wirusowym mRNA i jego kierowaniem na drogę degradacji, replikacja HBV może być także hamowana przez miRNA w sposób pośredni, w wyniku blokowania ekspresji czynników transkrypcyjnych niezbędnych dla zajścia tego procesu. MikroRNA, które działają w ten sposób, to m.in. miR-130 i miR-141 [24, 25]. Natomiast wyniki uzyskane na podstawie modelowania in silico sugerują, że miR-196b, miR-205, miR-345, miR-433, miR-511 oraz let-7 prawdopodobnie mogą bezpośrednio hamować replikację HBV przez wiązanie z sekwencjami wirusowymi [26].

Nie do końca jednoznaczne są dane dotyczące roli (w przebiegu wirusowego zapalenia wątroby typu B) miRNA-122, które jest swoiste dla wątroby i stanowi ok. 70\% frakcji miRNA w tym narządzie. Wykazano bowiem, że może ono jednocześnie działać przeciwwirusowo, jak i wspomagać replikację HBV, a ostateczny efekt wydaje się zależny od równowagi pomiędzy tymi dwoma procesami. Cyklina G1 wiąże się z białkiem p53, uniemożliwiając blokowanie przez p53 replikacji genów wirusowych. MikroRNA-122 może obniżać ekspresję swojego genu docelowego - cykliny G1, w konsekwencji czego p53 pozostaje związane z sekwencjami wzmacniającymi ekspresję HBV, 
blokując ich transkrypcję, przez co utrzymuje się niski poziom replikacji wirusa [27]. Z drugiej strony miR-122 obniża także ekspresję oksygenazy hemowej-1 (HO-1), w przypadku której wykazano zdolność hamowania ekspresji genów HBV [28]. W związku z tym aktywność przeciwwirusowa tego miRNA może być częściowo znoszona przez działanie hamujące na aktywność H0-1. Należy przy tym podkreślić, iż w przebiegu przewlekłej infekcji HBV obserwuje się obniżenie ekspresji miR-122, co jest również charakterystyczne dla raka wątrobowokomórkowego [29]. W przeciwieństwie do HCV, rola mir-122 w przebiegu infekcji HBV nie jest jednak do końca wyjaśniona.

\section{MikroRNA w zakażeniu wirusem HCV}

Na przewlekłe wirusowe zapalenie wątroby typu C cierpi na świecie ok. 130-150 mln osób, a ryzyko rozwoju marskości wątroby u zakażonych wynosi 15-30\%. W związku z brakiem szczepień ochronnych przeciwko HCV największe znaczenie w przeciwdziałaniu zakażeniu ma profilaktyka pierwotna w postaci zachowania higieny i ostrożności w trakcie kontaktów z chorymi oraz edukacja zdrowotna [30].

W przypadku wirusa HCV miRNA bezpośrednio uczestniczy w procesie zakażenia, przy czym kluczowa jest tu rola miR-122. Jak wcześniej wspomniano, stanowi ono przeważającą część puli wątrobowego miRNA i jest swoiste dla tego narządu. Badania wykazały, że miR-122 może być ściśle związane z tropizmem wirusa HCV do hepatocytów, a ponadto jest niezbędne dla jego replikacji [31]. Materiał genetyczny wirusa HCV stanowi jednoniciowa cząsteczka RNA, a w pobliżu jej końca 5' znajdują się dwa miejsca wiązania miR-122. W przeciwieństwie do fizjologicznej funkcji miRNA, polegającej na inicjacji degradacji docelowego RNA po związaniu z rozpoznawanymi sekwencjami, w przypadku infekcji HCV efekt jest przeciwny. Wiązanie miR-122 chroni koniec 5'-UTR RNA wirusa przed degradacją przez komórkową 5'-egzorybonukleazę Xrn1 i zwiększa jego stabilność, wspomagając tym samym replikację wirusa [32, 33]. Na podstawie badań dotyczących roli miRNA w infekcji HCV opracowany został eksperymentalny lek (miravirsen), 15-nukleotydowy modyfikowany oligonukleotyd komplementarny do miR-122. Podawany podskórnie miravirsen jest wychwytywany przez hepatocyty, gdzie wiąże pulę miR-122, w konsekwencji hamując replikację wirusa. Terapia antysensowna nie jest pomysłem nowym, jednak miravirsen jest pierwszym lekiem, którego celem jest miRNA, a dotychczasowe badania kliniczne wykazały, że jest on skuteczny w obniżaniu wiremii HCV i poprawie funkcji wątroby [34].

W bezpośrednią interakcję z genomem HCV wchodzi też wiele innych miRNA. Dla let-7b i miR-199a miejscem wiązania z wirusowym RNA, podobnie jak w przypadku miR-122, są obszary w obrębie regionu 5'-UTR, jednak w przeciwieństwie do mir-122, w przypadku związania let-7b i miR-199a dochodzi do hamowania replikacji HCV i ekspresji genów wirusowych [35, 36]. Negatywny wpływ na replikację wirusa mają również miR-196 i miR-448, których docelowe sekwencje znajdują się w regionach kodujących genomu HCV [37]. Także miR-181c może wchodzić w bezpośrednią interakcję z genomem HCV. Sekwencje docelowe dla tego miRNA znajdują się w obszarach kodujących glikoproteinę E1 otoczki wirusa oraz niestrukturalne białko NS5A. Zakażenie wirusem HCV prowadzi jednak do obniżenia ekspresji miR-181c w komórkach wątroby, co z kolei niweluje jego przeciwwirusową aktywność [38]. MikroRNA mogą także wywierać pośredni wpływ na przebieg zakażenia wirusem HCV poprzez ingerencję w procesy apoptozy, różnicowania komórek czy odpowiedzi immunologicznej. Wśród miRNA, których ekspresja jest zmieniona w przebiegu infekcji HCV, można wymienić m.in. miR-21, miR-24, miR-29, miR-149, miR-192, miR-301, miR-320 czy miR-638 [31]. Modyfikacje profilu ekspresji miRNA wpływają na zmianę wielu różnorodnych szlaków metabolicznych i sygnalnych, co może prowadzić do zniesienia właściwości przeciwwirusowych poszczególnych miRNA, wspomagać replikację wirusa lub skutkować innymi zmianami będącymi następstwami zakażenia. Konsekwencje tych zmian i wpływ na przebieg zakażenia nie są jednak jeszcze do końca poznane.

\section{MikroRNA w alkoholowej chorobie wątroby}

Nadużywanie alkoholu niesie ze sobą negatywne skutki zarówno społeczne, jak i zdrowotne. Wątroba jako narząd metabolizujący etanol jest bezpośrednio narażona na jego szkodliwe działanie. Pojęcie alkoholowej choroby wątroby (alcoholic liver disease - ALD) zawiera w sobie szerokie spektrum zmian zachodzących w tym narządzie i dotyczy takich procesów jak zapalenie i stłuszczenie wątroby, włóknienie i ostatecznie marskość poalkoholową wątroby [39]. Badania przeprowadzone w ostatnich latach wykazały, że alkohol i jego metabolity mogą nie tylko wykazywać bezpośrednią toksyczność, ale także indukować lub hamować ekspresję wybranych miRNA, wpływając w ten sposób na przebieg procesów patologicznych w wątrobie.

Chroniczne narażenie komórek wątroby na kontakt z etanolem prowadzi do indukcji stanu zapalnego, którego skutkiem może być zwłóknienie i marskość narządu. Istotną rolę w procesach zapalnych odgrywa m.in. miR-155. W badaniach prowadzonych na modelu mysim wykazano, że alkohol powoduje wzrost ekspresji tego miRNA w komórkach Kupffera (KCs), co z kolei prowadzi do zwiększenia produkcji prozapalnej cytokiny czynnika martwicy guza (TNF $\alpha$ ) przez te komórki. Prawdopodobną przyczyną deregulacji miR-155 jest wywołana etanolem

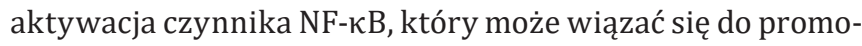
tora miR-155 i w ten sposób regulować jego transkrypcję [40].

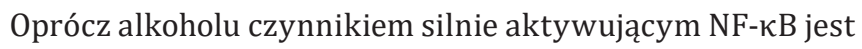
lipopolisacharyd (LPS). Podwyższone stężenie LPS w krążeniu po spożyciu alkoholu spowodowane jest z kolei zwiększeniem przepuszczalności ściany przewodu pokarmowego, co również może być częściowo wynikiem deregulacji na poziomie miRNA. Wykazano, że etanol powoduje zwiększenie ekspresji miR-212 w komórkach nabłonkowych jelit in vitro i u pacjentów z ALD. Potencjalnym celem miR-212 jest mRNA dla ZO-1 (zonula occludens-1), jednego z głównych białek wchodzących w skład międzykomórkowych połączeń ścisłych. Hamowanie ekspresji ZO-1 skutkuje z kolei zwiększeniem przepuszczalności jelit w wyniku rozluźnienia połączeń międzykomórkowych [41]. Poza rozwojem stanu zapalnego przewlekłe narażenie na działanie etanolu przyczynia się także do zwiększonej 
akumulacji lipidów w wątrobie, co w następstwie prowadzi do stłuszczenia narządu i zaburzenia jego funkcji. Yin i wsp. [42] wykazali, że duże znaczenie w rozwoju stłuszczenia może mieć miR-217, którego ekspresja w wątrobach myszy eksponowanych na działanie etanolu była ok. 30-krotnie wyższa w porównaniu do kontroli. Zwiększenie ilości miR-217 wiązało się z kolei $\mathrm{z}$ istotnym obniżeniem ekspresji sirtuiny 1 (SIRT1) związanej z regulacją metabolizmu glukozy i lipidów, co w konsekwencji skutkowało zwiększoną akumulacją tłuszczów w wątrobie. W innych badaniach prowadzonych na modelu zwierzęcym u myszy wywołano alkoholowe stłuszczenie wątroby, a następnie analizowano zmiany profilu miRNA. Zaobserwowano wzrost ekspresji miR-705 i miR-1224 oraz obniżenie ekspresji miR-27b, miR-182, miR-183, miR-199a, miR-200a, miR-214 i miR-322 [43]. Yeligar i wsp. [44] zaobserwowali, że obniżenie ekspresji miR-199 w sinusoidalnych komórkach nabłonkowych wątroby szczurów, którym wraz z dietą podawano etanol, związane jest ze wzrostem ekspresji mRNA endoteliny (ET-1) i czynnika transkrypcyjnego HIF-1 $\alpha$, co może promować stan zapalny w wątrobie. Obserwowane obniżenie ekspresji miR-27b, którego genem docelowym jest m.in. gen PHB pełniący rolę supresora nowotworowego, może modyfikować ryzyko rozwoju nowotworów [45]. Z kolei miRNA-200a obniża ekspresję genu MACC1 (metastasis associated in colon cancer 1) kodującego kluczowy regulator czynnika wzrostu hepatocytów (HGF), dzięki czemu hamuje wzrost komórek raka wątrobowokomórkowego [46]. Zarówno pro-, jak i antyonkogenne zmiany w wątrobowym profilu ekspresji miRNA pod wpływem alkoholu mogą częściowo tłumaczyć słabą zależność pomiędzy długotrwałym spożyciem alkoholu a występowaniem raka wątroby, w przeciwieństwie do silnego związku obserwowanego w przypadku nowotworów przełyku, gardła i jamy ustnej.

Indukcja lub represja różnych miRNA może również tłumaczyć wywołane alkoholem wzmocnienie replikacji wirusa HCV. Bukong i wsp. [47] wykazali, że zwiększenie replikacji HCV in vitro może być związane ze zwiększeniem ekspresji GW182 (białka biorącego udział w wyciszaniu ekspresji genów za pośrednictwem miRNA), HSP9o (białko szoku cieplnego) oraz miR-122, które jest niezbędne dla replikacji wirusa HCV. Prowadzone przez nich badania wykazały, że indukowany alkoholem wzrost poziomu HSP9o przyczynia się do zwiększenia stabilności kompleksu miR-122-GW182, wspomagając tym samych ochronne działanie miR-122 wobec genomu HCV. Indukowany alkoholem wzrost ekspresji miR-122 może wynikać również z aktywacji NF- $\mathrm{B}$, co zaobserwowali w swoich badaniach Hou i wsp. [48]. Ponadto wskazali oni inną możliwą drogę wzmacniania replikacji HCV, w którą zaangażowane jest miR-122. Odwrotnie niż w przypadku zakażenia wirusem HBV, przy zakażeniu HCV spadek ekspresji cykliny G1 prowadzi do zwiększenia replikacji wirusa, co wskazuje na udział cykliny G1 w regulacji ekspresji HCV.

\section{MikroRNA w niealkoholowej sttuszczeniowej chorobie wątroby}

Głównymi czynnikami ryzyka wystąpienia niealkoholowej stłuszczeniowej choroby wątroby (non-alcoholic fatty liver disease - NAFLD) są otyłość i cukrzyca typu II, ale znaczenie w rozwoju tej choroby ma również płeć, wiek i czynniki genetyczne. W spektrum chorób stłuszczeniowych zawarte są także stłuszczenie wątroby w przebiegu zakażenia wirusowego, zatrucia toksynami i lekami czy inne wtórne stłuszczenia wątroby, nie należy ich jednak zaliczać do NAFLD [49].

Wiele doświadczeń dotyczących miRNA w NAFLD prowadzonych jest z użyciem zwierzęcych modeli tej choroby. Badania prowadzone na myszach z indukowaną stłuszczeniową chorobą wątroby wykazały zwiększony poziom miR-34a, miR-155, miR-20ob i miR-221 oraz obniżoną ekspresję miR-29c, miR-122, miR-192 i miR-203 [50]. W badaniu materiału z biopsji wątroby pacjentów z NAFLD oraz osób zdrowych potwierdzono tę zależność w odniesieniu do miR-34a i miR-122 [51]. MikroRNA-34a związane jest przede wszystkim z regulacją cyklu komórkowego oraz apoptozy i uważane jest za supresor nowotworowy, natomiast miR-122 to omawiane wcześniej dominujące hepatocytarne miRNA. Innymi miRNA, których ekspresja wzrasta u zwierząt karmionych wysokokaloryczną dietą, są m.in. miR-146, miR-200a i miR-429, natomiast obniżoną ekspresję obserwowano w przypadku miR-27a, miR-122 i miR-451 [52]. MikroRNA-29, miR-146 i miR-155 poprzez swoje geny docelowe związane są z regulacją odpowiedzi immunologicznej [53, 54, 55], natomiast zmieniona ekspresja miR-27 i miR-200a może wpływać na procesy zachodzące podczas karcinogenezy, co jest zbieżne z obserwacją dotyczącą zwiększonego ryzyka występowania nowotworów wątroby wśród pacjentów z NAFLD [45, 56]. W wątrobach myszy karmionych dietą bogatotłuszczową obserwowano także istotnie obniżoną ekspresję miR-467b, którego przypuszczalnym celem jest koniec 3' mRNA lipazy lipoproteinowej (LPL). Obniżony poziom tego miRNA koreluje ze zwiększoną ekspresją LPL, co wpływa na zwiększenie insulinooporności hepatocytów i rozwój stłuszczenia wątroby [57]. Inne badania na zwierzęcym modelu NAFLD wykazały istotnie podwyższoną ekspresję 17 różnych miRNA, z których miR-705 i miR-1224 podwyższone były także u myszy z indukowaną ALD, natomiast miR-182, miR-183 i miR-199a - w przeciwieństwie do modelu ALD - były obniżone, co podkreśla różnice w patogenezie tych schorzeń [43]. Ważną rolę w stłuszczeniu wątroby może również pełnić miR-15b. Poziom tego miRNA jest podwyższony w surowicy pacjentów ze stłuszczeniową chorobą wątroby. Ponadto wykazano jego zwiększoną ekspresję w wątrobach szczurów z NAFLD. Podwyższony poziom miR-15b wpływa prawdopodobnie na zwiększenie akumulacji triglicerydów i upośledzenie metabolizmu glukozy w hepatocytach, co skutkuje postępującym stłuszczeniem komórek wątroby [58]. Zhang i wsp. [59] wykazali z kolei, że miR-125b wpływał ochronnie na rozwój stłuszczenia wątroby u myszy, u których stosowano dietę bogatotłuszczową.

\section{MikroRNA w polekowym i toksycznym uszkodzeniu wątroby}

Polekowe uszkodzenie wątroby (drug-induced liver injury - DILI) może mieć różny charakter, od 1) indukcji stanu zapalnego, co jest m.in. podstawą mechanizmu hepatotoksyczności fluorochinolonów i metyldopy, przez 2) stłuszczenie powodowane 
m.in. przez metotreksat, amiodaron i tamoksyfen, aż po 3) martwicę, która może być skutkiem zatrucia paracetamolem [60]. Analiza profilu miRNA w odniesieniu do DILI ma istotne znaczenie, ponieważ swoiste zmiany ekspresji miRNA mogą mieć potencjalnie dużą wartość prognostyczną w polekowym uszkodzeniu wątroby.

Dotychczasowe badania wskazują, że zmiany profilu ekspresji miRNA są odmienne w zależności od leku wywołującego uszkodzenie. Na przykład w wątrobach szczurów, którym podawano acetaminofen (paracetamol) lub czterochlorek węgla, obserwowano istotny spadek ekspresji miR-298 i miR-370 [61], natomiast uszkodzenie wątroby indukowane przez tamoksyfen prowadziło do modyfikacji ekspresji m.in. miR-16, miR-17-5p, miR-20b, miR-34a, miR-92, miR-106a, miR-152, miR-192 czy miR-365 [62]. Obserwowane zmiany ekspresji licznych miRNA w wątrobie narażonej na działanie toksyczne leków mogą być związane z ingerencją w replikację DNA, cykl komórkowy, regulację apoptozy czy też procesy epigenetyczne. Z kolei Endo i wsp. wykazali, że u myszy, którym dootrzewnowo podawano halotan, istotnej zmianie uległa ekspresja ok. 30-50\% spośród ponad 200 przebadanych mikroRNA. Autorzy wykazali też, że obniżenie ekspresji miR-106b u badanych zwierząt prowadzi w konsekwencji do znacznego wzrostu ekspresji czynnika transkrypcyjnego STAT3 związanego z regulacją procesów zapalnych. Autorzy postulowali, że indukowana przez STAT3 ekspresja prozapalnej interleukiny 17 może stanowić mechanizm uszkodzenia wątroby zależnego od halotanu [63]. Poza niewątpliwym wkładem w rozwój wiedzy na temat mechanizmów indukowanego lekami uszkodzenia wątroby analiza profilu mikroRNA może mieć także duże znaczenie diagnostyczne. Liczne badania dotyczące ekspresji miRNA w osoczu lub surowicy krwi dowodzą bowiem, że cząsteczki te mogą być dobrym biomarkerem uszkodzenia wątroby już na wczesnym etapie [64].

Oprócz zatruć lekami uszkodzenie wątroby może być także indukowane w wyniku narażenia na inne substancje toksyczne. Do ostrego zatrucia dochodzi najczęściej w sposób przypadkowy, tak jak ma to miejsce w zatruciu muchomorem sromotnikowym. W przypadku zatruć przewlekłych do niewydolności wątroby może przyczyniać się wciąż wzrastające zanieczyszczenie środowiska. Yoshioka i wsp. [65] wykazali istotny spadek ekspresji miR-101a i miR-122 w wątrobie myszy z uszkodzeniem tego narządu indukowanym dioksynami (TCDD). MikroRNA-101a posiada sekwencję komplementarną do końca 3'UTR cyklooksygenazy 2 (COX-2), w związku z czym bierze udział w hamowaniu jej ekspresji [66]. Obniżenie poziomu tego miRNA wiąże się zatem ze wzrostem ekspresji COX-2, co może mieć znaczenie w rozwoju dioksyno-zależnego uszkodzenia wątroby u myszy. Profil ekspresji tych miRNA podlega prawdopodobnie dynamicznym zmianom i zależy od czasu, który upłynął od ekspozycji na TCDD, o czym świadczą różnice pomiędzy wynikami Yoshioka i wsp. [65] a wcześniejszymi badaniami prowadzonymi przez Moffat i wsp. [67]. W badaniach prowadzonych na szczurach, które narażone były na działanie aflatoksyny B1 (wytwarzanej przez grzyby z rodzaju Aspergillus), w wątrobach zwierząt obserwowano zmienioną ekspresję miR-34a, miR-122, miR-221 oraz należących do klastra miRNA 17-92: miR-17, miR-19a, miR-19b, miR-20a, i miR-92a [68]. Zmianę ekspresji miR-34a obserwowano też w wątrobach myszy, którym przez 28 dni podawano benzo(a) piren [69]. Biorąc pod uwagę związek miR-34a z regulacją cyklu komórkowego, zmiany w jego ekspresji mogą być odpowiedzialne za mutagenne działanie omawianych toksyn.

\section{MikroRNA w innych schorzeniach prowadzących do niewydolności wątroby}

Poza omówionymi przykładami do niewydolności wątroby może dojść także w przebiegu innych schorzeń, m.in. chorób autoimmunologicznych, metabolicznych, przebiegających z przewlekłą cholestazą, w zaburzeniach krążenia czy nowotworach.

Jedną z częstszych chorób autoimmunologicznych prowadzących do niewydolności wątroby jest pierwotna marskość żółciowa (primary biliary cirrhosis - PBC). W jej przebiegu dochodzi do zniszczenia drobnych wewnątrzwątrobowych przewodów żółciowych, co w konsekwencji prowadzi do przewlekłej cholestazy i niewydolności narządu. Choroba ta dotyka głównie kobiety po 30. r.ż. Przyczyny PBC nie są do końca znane, ale sugeruje się, że wpływ na jej rozwój mogą mieć czynniki infekcyjne i środowiskowe oraz uwarunkowania genetyczne. Badania wykazały zmienioną ekspresję niektórych miRNA w wątrobach pacjentów z PBC, m.in. miR-26a, miR-122a, miR-328 i miR-506 [70, 71]. Ponadto wykazano, że zwiększona ekspresja miR-506 w cholangiocytach pacjentów z PBC może negatywnie wpływać na funkcje wydzielnicze dróg żółciowych poprzez hamowanie aktywności białka transportowego AE2. Poza tym, że analiza ekspresji mikroRNA może być pomocna w poznaniu molekularnych mechanizmów powstawania i przebiegu chorób autoimmunologicznych wątroby, może być również przydatna w ich diagnostyce opartej na analizie krążącego miRNA w osoczu [72, 73]. Inną chorobą wątroby związaną z przewlekłą cholestazą jest pierwotne stwardniające zapalenie przewodów żółciowych (primary sclerosing cholangitis - PSC). Schorzenie to charakteryzuje się naciekami zapalnymi i postępującym włóknieniem wewnątrzwątrobowych i/lub pozawątrobowych przewodów żółciowych. W przeciwieństwie do PBC i autoimmunologicznego zapalenia wątroby, choroba ta występuje głównie u mężczyzn. Jak dotąd nie przeprowadzono badań dotyczących roli miRNA w patogenezie PSC, istnieją jednak dane na temat możliwego wykorzystania miRNA jako narzędzia do wykrywania we wczesnym stadium raka dróg żółciowych (cholangiocarcinoma - CC), będącego jednym z powikłań w przebiegu PBC. Voigtländer i wsp. wykazali różnice w ekspresji miR-26a, miR-30b, miR-122, miR-126, miR-194 i miR-1281 między pacjentami z PSC i CC, a także między chorymi i grupą kontrolną [74]. Z kolei Bernuzzi i wsp. wskazali na miR-194, miR-200c, miR-222 i miR-483-5p jako pomocne w wykrywaniu wymienionych wcześniej schorzeń [75]. W obu badaniach odnotowano także nieswoiste zmiany dotyczące ekspresji niektórych mikroRNA, np. miR-122 czy miR-194, które obserwowane są w wielu innych schorzeniach wątroby. Wydaje się, że badanie szerszego panelu ekspresji miRNA może okazać się w przyszłości przydatne $\mathrm{w}$ diagnostyce i monitorowaniu przebiegu stosunkowo słabo poznanej choroby, jaką jest PSC. 
Niektóre przewlekłe choroby wątroby istotnie zwiększają ryzyko rozwoju raka wątrobowokomórkowego (hepatocellular carcinoma - HCC). Mechanizmy indukujące karcinogenezę nie są do końca poznane, ale mikroRNA może być jednym z czynników biorących udział w tym procesie. Na przykład ekspresja miR-21 i miR-183 jest istotnie podwyższona w tkance HCC w porównaniu do prawidłowych hepatocytów, a oba wymienione miRNA hamują aktywność supresorów nowotworowych, w tym białka PDCD4, co wskazuje na potencjalny mechanizm regulacji kancerogenezy przez mikroRNA [76, 77]. Innymi przykładami mogą być miR-34a, miR-145, miR-155 czy miR-222 [78, 79, 80, 81]. Zmiana ekspresji tych mikroRNA, często powodowana przez czynniki wywołujące pierwotną chorobę wątroby, w konsekwencji wpływa na aktywność wielu białek związanych z regulacją apoptozy, wzrostu i podziału komórki, co może być bezpośrednią przyczyną progresji nowotworowej w dotkniętej chorobą tkance.

Zestawienie najważniejszych miRNA, które mają znaczenie w przebiegu chorób wątroby wraz z ich genami docelowymi i możliwymi szlakami modyfikowanymi w wyniku zmienionej ekspresji miRNA, przedstawiono w tabeli 1.

\section{Krążące mikroRNA}

Dzięki znacznemu zwiększeniu czułości i przepustowości metod biologii molekularnej w ostatniej dekadzie obecnie profil ekspresji miRNA może być oznaczany nie tylko na podstawie analizy wewnątrzkomórkowych miRNA, ale także w płynach ustrojowych. Analiza miRNA krążących w osoczu lub surowicy jest nieinwazyjną i stosunkowo łatwą metodą, która niesie ze sobą duże możliwości zastosowania w celu poszukiwania biomarkerów różnych schorzeń. Wydaje się bowiem, że zmiany profilu osoczowego miRNA, podobnie jak w przypadku frakcji komórkowej, zależne są od etiologii schorzenia i mogą stanowić ważny marker diagnostyczny oraz prognostyczny w przypadku chorób przewlekłych, nowotworowych, a także ostrych zatruć. W procesach nowotworowych, zatruciach oraz różnorodnych chorobach zapalnych miRNA znajdujące się w obumierających komórkach przedostaje się do krążenia, dlatego osoczowy profil odzwierciedla w pewnym stopniu swoistą pulę miRNA zawartą w komórkach i tkankach objętych procesem chorobowym. Jednocześnie, w przeciwieństwie do tkankowej frakcji RNA, bardzo podatnej na degradację, czas półtrwania cząsteczek miRNA w osoczu jest relatywnie długi. W chorobach wątroby podstawowym miRNA, którego zawartość w osoczu zmienia się w przebiegu chorób wątroby, jest wcześniej opisywane miR-122 - główne miRNA hepatocytów. Zmieniony poziom jego ekspresji w osoczu wskazuje na uszkodzenie wątroby, ale zmiany te, podobnie jak inne markery wątrobowe, nie są swoiste dla jednostki chorobowej. Niemniej jednak cząsteczka ta może być pomocna w diagnostyce nowotworów wątroby lub pełnić rolę wskaźnika wczesnego uszkodzenia wątroby o różnej etiologii [82]. Pozostałe mikroRNA, które mogą być brane pod uwagę jako potencjalnie istotne biomarkery chorób

TABELA 1. Wykaz wybranych miRNA o udowodnionym znaczeniu w patogenezie i przebiegu chorób wątroby

\begin{tabular}{|c|c|c|c|c|}
\hline miRNA & Regulowane geny & Schorzenie & Potencjalnie modyfikowane szlaki & Źródła \\
\hline miR-15 & BCL2, FUT2 & HBV, NAFLD, HCC & regulacja apoptozy, progresja nowotworowa & {$[83,84]$} \\
\hline miR-16 & MAP7, CDS2, PRDM4, BCL2 & HBV, NALD, DILI & różnicowanie i regulacja wzrostu komórek & {$[83,85]$} \\
\hline $\operatorname{miR}-21$ & $\begin{array}{l}\text { TPM1, PDCD4, PTEN, RECK, } \\
\text { RHOB }\end{array}$ & HBV, HCV, NAFLD, DILI, HCC & $\begin{array}{l}\text { regulacja cyklu komórkowego, supresja } \\
\text { nowotworowa }\end{array}$ & {$[77,86,87,88]$} \\
\hline $\operatorname{miR}-24$ & FAF1, E2F2, MYC & HCV, DILI & cykl komórkowy, apoptoza & {$[89,90]$} \\
\hline miR-27 & $P H B, A P C$ & HCV, ALD, NAFLD, DILI & supresja nowotworowa & {$[45,91]$} \\
\hline $\operatorname{miR}-29$ & TCL1, PTEN, MMP-2, B7-H3 & HBV, HCV, NAFLD, DILI & $\begin{array}{l}\text { proliferacja, onkogeneza, odpowiedź } \\
\text { immunologiczna }\end{array}$ & {$[11,53,92,93]$} \\
\hline miR-34a & CCND1, CDK6, PPARA, SIRT1 & $\begin{array}{l}\text { HCV, ALD, NAFLD, TOX, DILI, } \\
\text { HCC }\end{array}$ & cykl komórkowy, apoptoza, metabolizm lipidów & {$[94,95]$} \\
\hline miR-92 & BCL2L11, CDH1 & HCV, DILI, TOX & apoptoza, proliferacja & {$[96,97]$} \\
\hline miR-101 & ATM, PRKDC, DUSP1, COX2 & NAFLD, TOX, HCC & $\begin{array}{l}\text { regulacja cyklu komórkowego, onkogeneza, procesy } \\
\text { zapalne }\end{array}$ & {$[66,98,99]$} \\
\hline $\operatorname{miR}-122$ & $\begin{array}{l}\text { BCL2L2, CCNG1, CUX1, } \\
\text { P4HA1 }\end{array}$ & $\begin{array}{l}\text { HBV, HCV, ALD, NAFLD, DILI, } \\
\text { TOX, HCC }\end{array}$ & apoptoza, proliferacja, cykl komórkowy, włóknienie & {$[100,101,102,103]$} \\
\hline miR-146 & IRAK1, TRAF6 & HCV, NAFLD, DILI & odpowiedź immunologiczna & [54] \\
\hline miR-155 & FADD, CASP3, MYD88 & HCV, ALD, NAHLD, DILI, HCC & apoptoza, odpowiedź immunologiczna & {$[55,104]$} \\
\hline miR-192 & NID1, SLC39A6, MDM2 & HBV, HCV, NAFLD, DILI, TOX & $\begin{array}{l}\text { interakcje z macierzą pozakomórkową, apoptoza, } \\
\text { migracja komórek }\end{array}$ & {$[105,106,107]$} \\
\hline $\operatorname{miR}-199 a$ & SMAD4, CAV2, NLK & HBV, HCV, NAFLD, TOX, HCC & $\begin{array}{l}\text { nowotworzenie, regulacja transkrypcji i wzrostu } \\
\text { komórki }\end{array}$ & {$[108,109,110]$} \\
\hline miR-200 & FAP-1, ZEB1, ZEB2, MACC1 & ALD, NAFLD, DILI, TOX, HCC & $\begin{array}{l}\text { regulacja transkrypcji, włóknienie, nowotworzenie, } \\
\text { remodeling tkankowy }\end{array}$ & {$[56,111]$} \\
\hline miR-365 & CCND1, BCL2, CDC25A & HBV, DILI & regulacja cyklu komórkowego i apoptozy & {$[112,113]$} \\
\hline miR-638 & PLD1, TP53, PTEN, BRCA1 & $\mathrm{HBV}, \mathrm{HCV}$ & apoptoza, transdukcja sygnałów, nowotworzenie & {$[114,115]$} \\
\hline
\end{tabular}

HBV - wirusowe zapalenie wątroby typu B; NAFLD - niealkoholowa stłuszczeniowa choroba wątroby; HCC - rak wątrobowokomórkowy; DILI - polekowe uszkodzenie wątroby; HCV - wirusowe zapalenie wątroby typu C; ALD - alkoholowa choroba wątroby; TOX - uszkodzenie wątroby wywołane toksynami 
TABELA 2. Wpływ wybranych chorób na ekspresję miRNA w komórkach wątroby (badania in vivo i in vitro) oraz zawartość miRNA w osoczu

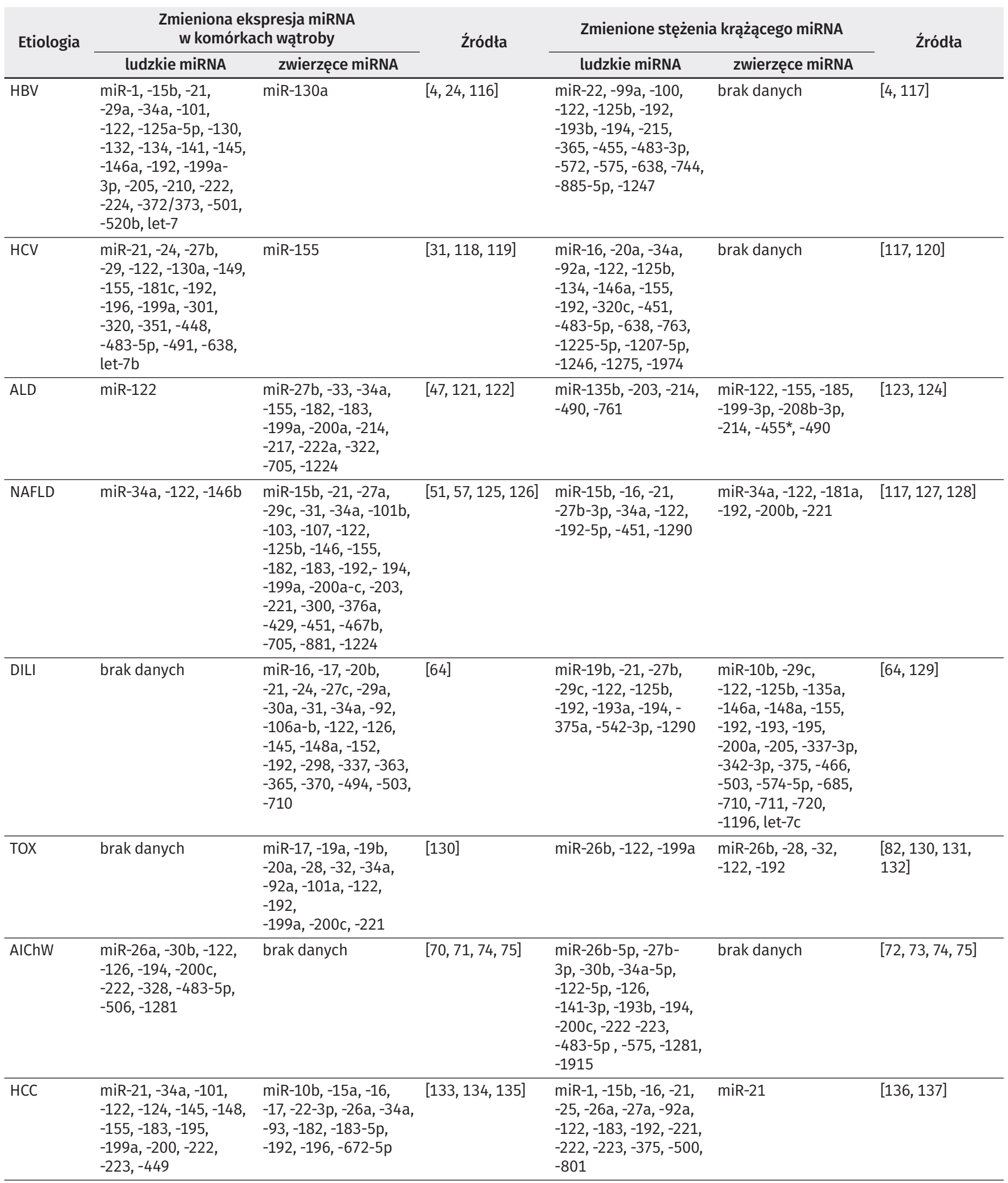

HBV - wirusowe zapalenie wątroby typu B; HCV - wirusowe zapalenie wątroby typu C; ALD - alkoholowa choroba wątroby; NAFLD - niealkoholowa stłuszczeniowa choroba wątroby; DILI - polekowe uszkodzenie wątroby; TOX - uszkodzenie wątroby wywołane toksynami; AIChW - autoimmunologiczne choroby wątroby; HCC rak wątrobowokomórkowy

wątroby, prezentowane są w tabeli 2. Dotychczas przeprowadzone badania nie doprowadziły do konsensusu w kwestii zastosowania diagnostycznego miRNA. Wstępne wyniki wskazują jednak, że o ile pojedyncze miRNA nie odzwierciedla swoiście stanu klinicznego pacjenta, o tyle ocena zmian profilu osoczowego puli krążących miRNA jest bardziej informatywna i pod warunkiem weryfikacji uzyskanych danych może być potencjalnie zastosowana w diagnostyce. 


\section{PODSUMOWANIE}

Od chwili odkrycia miRNA cząsteczki te stały się atrakcyjnym tematem badań naukowców z różnych dziedzin medycyny, a poznanie mechanizmów, w których biorą one udział, istotnie poszerzyło wiedzę o funkcjonowaniu organizmów na poziomie molekularnym. Cząsteczki te zaangażowane są w regulację ekspresji genów, w związku z czym mogą kontrolować liczne procesy fizjologiczne i patologiczne, a wszelkie zmiany w profilu ich ekspresji mogą mieć odbicie w zmienionym funkcjonowaniu komórek i narządów. W przypadku chorób wątroby wiele różnych czynników może prowadzić do przewlekłego zapalenia, zwłóknienia i ostatecznie marskości tego narządu. Pomimo podobnego obrazu klinicznego, patogeneza tych schorzeń jest jednak odmienna, a różnice występują na poziomie mechanizmów regulacyjnych, w tym mediowanych przez miRNA. Analiza tych zmian oraz ich konsekwencji na poziomie regulowanych genów i szlaków dostarcza nowych danych na temat patogenezy. Co więcej, w wirusowych zapaleniach wątroby ekspresja określonych miRNA jest nie tylko związana z postępowaniem procesu chorobowego, ale ma ścisły związek z tropizmem i replikacją wirusa, co może być wykorzystane w leczeniu. Oprócz badań bioptatów wątroby możliwa jest także ocena profilu osoczowego miRNA. Dotychczasowe badania wskazują, że takie małoinwazyjne badanie może dostarczyć informacji na temat aktualnego stanu wątroby i może być w przyszłości zastosowane w celu wczesnej diagnostyki chorób wątroby, a także oceny ich przebiegu oraz rokowania.

\section{PIŚMIENNICTWO}

1. Dong H, Lei J, Ding L, Wen Y, Ju H, Zhang X. MicroRNA: Function, detection, and bioanalysis. Chem Rev 2013;113(8):6207-33.

2. Reid G, Kirschner MB, van Zandwijk N. Circulating microRNAs: Association with disease and potential use as biomarkers. Crit Rev Oncol Hematol 2011;80(2):193-208.

3. Hepatitis B. Fact sheet 204. World Healt Organization; 2016. http://www. who.int/mediacentre/factsheets/fs204/en/ (13.04.2016).

4. Sarkar N, Chakravarty R. Hepatitis B. Virus infection, microRNAs and liver disease. Int J Mol Sci 2015;16(8):17746-62.

5. Elmore LW, Hancock AR, Chang SF, Wang XW, Chang S, Callahan CP, et al. Hepatitis B virus X protein and p53 tumor suppressor interactions in the modulation of apoptosis. Proc Natl Acad Sci U S A 1997;94(26):14707-12.

6. Feng Z, Zhang C, Wu R, Hu W. Tumor suppressor $\mathrm{p} 53$ meets microRNAs. J Mol Cell Biol 2011;3(1):44-50. doi: 10.1093/jmcb/mjq040.

7. Lim KH, Choi HS, Park YK, Park ES, Shin GC, Kim DH, et al. HBx-induced $\mathrm{NF}-\kappa \mathrm{B}$ signaling in liver cells is potentially mediated by the ternary complex of HBx with p22-FLIP and NEMO. PLoS One 2013;8(3):e57331.

8. Li JF, Dai XP, Zhang W, Sun SH, Zeng Y, Zhao GY, et al. Upregulation of microRNA-146a by hepatitis B virus X protein contributes to hepatitis development by downregulating complement factor H. MBio 2015;6(2):e02459-14.

9. Scisciani C, Vossio S, Guerrieri F, Schinzari V, De Iaco R, D’Onorio de Meo $\mathrm{P}$, et al. Transcriptional regulation of miR-224 upregulated in human HCCs by NFKB inflammatory pathways. J Hepatol 2012;56(4):855-61.

10. Wu G, Yu F, Xiao Z, Xu K, Xu J, Tang W, et al. Hepatitis B virus X protein downregulates expression of the miR-16 family in malignant hepatocytes in vitro. Br J Cancer 2011;105(1):146-53.

11. Kong G, Zhang J, Zhang S, Shan C, Ye L, Zhang X. Upregulated microRNA29a by hepatitis B virus X protein enhances hepatoma cell migration by targeting PTEN in cell culture model. PLoS One 2011;6(5):e19518.
12. Ren M, Qin D, Li K, Qu J, Wang L, Wang Z, et al. Correlation between hepatitis B virus protein and microRNA processor Drosha in cells expressing HBV. Antiviral Res 2012;94(3)225-31.

13. Bandopadhyay M, Banerjee A, Sarkar N, Panigrahi R, Datta S, Pal A, et al. Tumor suppressor micro RNA miR-145 and onco micro RNAs miR-21 and miR-222 expressions are differentially modulated by hepatitis B virus $\mathrm{X}$ protein in malignant hepatocytes. BMC Cancer 2014;14:721.

14. Wang Y, Lu Y, Toh ST, Sung WK, Tan P, Chow P, et al. Lethal-7 is downregulated by the hepatitis $B$ virus $x$ protein and targets signal transducer and activator of transcription 3. J Hepatol 2010;53(1):57-66. doi: 10.1016/j.jhep.2009.12.043.

15. Wei X, Xiang T, Ren G, Tan C, Liu R, Xu X, et al. MiR-101 is down-regulated by the hepatitis $B$ virus $x$ protein and induces aberrant DNA methylation by targeting DNA methyltransferase 3A. Cell Signal 2013;25(2):439-46. doi: 10.1016/j.cellsig.2012.10.013.

16. Wei X, Tan C, Tang C, Ren G, Xiang T, Qiu Z, et al. Epigenetic repression of miR-132 expression by the hepatitis B virus x protein in hepatitis B virus-related hepatocellular carcinoma. Cell Signal 2013;25(5):1037-43.

17. Zhang T, Zhang J, Cui M, Liu F, You X, Du Y, et al. Hepatitis B virus X protein inhibits tumor suppressor miR-205 through inducing hypermethylation of miR-205 promoter to enhance carcinogenesis. Neoplasia 2013;15(11):1282-91.

18. Zhang X, Zhang E, Ma Z, Pei R, Jiang M, Schlaak JF, et al. Modulation of hepatitis $B$ virus replication and hepatocyte differentiation by MicroRNA-1. Hepatology 2011;53(5):1476-85.

19. Dai X, Zhang W, Zhang H, Sun S, Yu H, Guo Y, et al. Modulation of HBV replication by microRNA-15b through targeting hepatocyte nuclear factor $1 \alpha$. Nucleic Acids Res 2014;42(10):6578-90.

20. Guo H, Liu H, Mitchelson K, Rao H, Luo M, Xie L, et al. MicroRNAs-372/373 promote the expression of hepatitis B virus through the targeting of nuclear factor I/B. Hepatology 2011;54(3):808-19.

21. Jin J, Tang S, Xia L, Du R, Xie H, Song J, et al. MicroRNA-501 promotes HBV replication by targeting HBXIP. Biochem Biophys Res Commun 2013;430(4):1228-33.

22. Zhang GL, Li YX, Zheng SQ, Liu M, Li X, Tang H. Suppression of hepatitis B virus replication by microRNA-199a-3p and microRNA-210. Antiviral Res 2010;88(2):169-75.

23. Potenza N, Papa U, Mosca N, Zerbini F, Nobile V, Russo A. Human microRNA hsa-miR-125a-5p interferes with expression of hepatitis B virus surface antigen. Nucleic Acids Res 2011;39(12):5157-63.

24. Huang JY, Chou SF, Lee JW, Chen HL, Chen CM, Tao MH, et al. MicroRNA130a can inhibit hepatitis B virus replication via targeting PGC1 $\alpha$ and PPAR $\gamma$. RNA 2015;21(3):385-400.

25. Hu W, Wang X, Ding X, Li Y, Zhang X, Xie P, et al. MicroRNA-141 represses HBV replication by targeting PPARA. PLoS One 2012;7(3):e34165.

26. Wu FL, Jin WB, Li JH, Guo AG. Targets for human encoded microRNAs in HBV genes. Virus Genes 2011;42(2):157-61.

27. Wang S, Qiu L, Yan X, Jin W, Wang Y, Chen L, et al. Loss of microRNA 122 expression in patients with hepatitis $B$ enhances hepatitis $B$ virus replication through cyclin G(1)-modulated P53 activity. Hepatology 2012;55(3):730-41.

28. Qiu L, Fan H, Jin W, Zhao B, Wang Y, Ju Y, et al. MiR-122-induced downregulation of HO-1 negatively affects miR-122-mediated suppression of HBV. Biochem Biophys Res Commun 2010;398(4):771-7.

29. Tsai WC, Hsu PW, Lai TC, Chau GY, Lin CW, Chen CM, et al. MicroRNA-122, a tumor suppressor microRNA that regulates intrahepatic metastasis of hepatocellular carcinoma. Hepatology 2009;49(5):1571-82.

30. Hepatitis C. Fact sheet 164. World Healt Organization; 2016. http://www. who.int/mediacentre/factsheets/fs164/en/ (13.04.2016).

31. Conrad KD, Niepmann M. The role of microRNAs in hepatitis C virus RNA replication. Arch Virol 2014;159(5):849-62.

32. Li Y, Masaki T, Yamane D, McGivern DR, Lemon SM. Competing and noncompeting activities of miR-122 and the 5' exonuclease Xrn1 in regulation of hepatitis C virus replication. Proc Natl Acad Sci U S A 2013;110(5):1881-6. doi: 10.1073/pnas.1213515110.

33. Machlin ES, Sarnow P, Sagan SM. Masking the 5' terminal nucleotides of the hepatitis $C$ virus genome by an unconventional microRNA-target RNA complex. Proc Natl Acad Sci U S A 2011;108(8):3193-8.

34. Motavaf M, Safari S, Alavian SM. Targeting microRNA-122: walking on cutting edge of hepatitis C virus infection therapy. Acta Virol 2014;58(4): 301-8. 
35. Cheng JC, Yeh YJ, Tseng CP, Hsu SD, Chang YL, Sakamoto N, et al. Let$7 \mathrm{~b}$ is a novel regulator of hepatitis $\mathrm{C}$ virus replication. Cell Mol Life Sci 2012;69(15):2621-33.

36. Murakami Y, Aly HH, Tajima A, Inoue I, Shimotohno K. Regulation of the hepatitis C virus genome replication by miR-199a. J Hepatol 2009;50(3):453-60.

37. Pedersen IM, Cheng G, Wieland S, Volinia S, Croce CM, Chisari FV, et al. Interferon modulation of cellular microRNAs as an antiviral mechanism. Nature 2007;449(7164):919-22.

38. Mukherjee A, Shrivastava S, Bhanja Chowdhury J, Ray R, Ray RB. Transcriptional suppression of miR-181c by hepatitis $\mathrm{C}$ virus enhances homeobox A1 expression. J Virol 2014;88(14):7929-40.

39. Gramenzi A, Caputo F, Biselli M, Kuria F, Loggi E, Andreone P, et al. Review article: alcoholic liver disease: pathophysiological aspects and risk factors. Aliment Pharmacol Ther 2006;24(8):1151-61.

40. Bala S, Marcos M, Kodys K, Csak T, Catalano D, Mandrekar P, et al. Upregulation of microRNA-155 in macrophages contributes to increased tumor necrosis factor alpha\} (TNF alpha\}) production via increased mRNA half-life in alcoholic liver disease. J Biol Chem 2011;286(2):1436-44.

41. Tang Y, Banan A, Forsyth CB, Fields JZ, Lau CK, Zhang LJ, et al. Effect of alcohol on miR-212 expression in intestinal epithelial cells and its potential role in alcoholic liver disease. Alcohol Clin Exp Res 2008;32(2):355-64.

42. Yin H, Hu M, Zhang R, Shen Z, Flatow L, You M. MicroRNA-217 promotes ethanol-induced fat accumulation in hepatocytes by down-regulating SIRT1. J Biol Chem 2012;287(13):9817-26.

43. Dolganiuc A, Petrasek J, Kodys K, Catalano D, Mandrekar P, Velayudham A, et al. MicroRNA expression profile in Lieber-DeCarli diet-induced alcoholic and methionine choline deficient diet-induced nonalcoholic steatohepatitis models in mice. Alcohol Clin Exp Res 2009;33(10):1704-10.

44. Yeligar S, Tsukamoto H, Kalra VK. Ethanol-induced expression of ET-1 and ET-BR in liver sinusoidal endothelial cells and human endothelial cells involves hypoxia-inducible factor-1alpha and microrNA-199. J Immunol 2009;183(8):5232-43.

45. Kang T, Lu W, Xu W, Anderson L, Bacanamwo M, Thompson W, et al. MicroRNA-27 (miR-27) targets prohibitin and impairs adipocyte differentiation and mitochondrial function in human adipose-derived stem cells. J Biol Chem 2013;288(48):34394-402. doi: 10.1074/jbc.M113.514372.

46. Feng J, Wang J, Chen M, Chen G, Wu Z, Ying L, et al. MiR-200a suppresses cell growth and migration by targeting MACC1 and predicts prognosis in hepatocellular carcinoma. Oncol Rep 2015;33(2):713-20.

47. Bukong TN, Hou W, Kodys K, Szabo G. Ethanol facilitates hepatitis C virus replication via up-regulation of GW182 and heat shock protein 90 in human hepatoma cells. Hepatology 2013;57(1):70-80.

48. Hou W, Bukong TN, Kodys K, Szabo G. Alcohol facilitates HCV RNA replication via up-regulation of miR-122 expression and inhibition of cyclin G1 in human hepatoma cells. Alcohol Clin Exp Res 2013;37(4):599-608.

49. Habior A. Nonalcoholic fatty liver disease and obesity. Post Nauk Med 2013;5b:31-7.

50. Pogribny IP, Starlard-Davenport A, Tryndyak VP, Han T, Ross SA, Rusyn I, et al. Difference in expression of hepatic microRNAs miR-29c, miR-34a, miR-155, and miR-200b is associated with strain-specific susceptibility to dietary nonalcoholic steatohepatitis in mice. Lab Invest 2010;90(10): 1437-46.

51. Cheung O, Puri P, Eicken C, Contos MJ, Mirshahi F, Maher JW, et al. Nonalcoholic steatohepatitis is associated with altered hepatic microRNA expression. Hepatology 2008;48(6):1810-20. doi: 10.1002/hep.22569.

52. Alisi A, Da Sacco L, Bruscalupi G, Piemonte F, Panera N, De Vito R, et al. Mirnome analysis reveals novel molecular determinants in the pathogenesis of diet-induced nonalcoholic fatty liver disease. Lab Invest 2011;91(2):283-93.

53. Xu H, Cheung IY, Guo HF, Cheung NK. MicroR NA miR-29 modulates expression of immunoinhibitory molecule B7-H3: potential implications for immune based therapy of human solid tumors. Cancer Res 2009;69(15):6275-81

54. Taganov KD, Boldin MP, Chang KJ, Baltimore D. NF-kappaB-dependent induction of microRNA miR-146, an inhibitor targeted to signaling proteins of innate immune responses. Proc Natl Acad Sci U S A 2006;103(33):124816. doi: $10.1073 /$ pnas.0605298103.

55. Tang B, Xiao B, Liu Z, Li N, Zhu ED, Li BS, et al. Identification of MyD88 as a novel target of miR-155, involved in negative regulation of Helicobacter pylori-induced inflammation. FEBS Lett 2010;584(8):1481-6. doi: 10.1016/j.febslet.2010.02.063.
56. Park SM, Gaur AB, Lengyel E, Peter ME. The miR-200 family determines the epithelial phenotype of cancer cells by targeting the E-cadherin repressors ZEB1 and ZEB2. Genes Dev 2008;22(7):894-907.

57. Ahn J, Lee $\mathrm{H}$, Chung $\mathrm{CH}, \mathrm{Ha}$ T. High fat diet induced downregulation of microRNA-467b increased lipoprotein lipase in hepatic steatosis. Biochem Biophys Res Commun 2011;414(4):664-9.

58. Zhang Y, Cheng X, Lu Z, Wang J, Chen H, Fan W, et al. Upregulation of miR$15 \mathrm{~b}$ in NAFLD models and in the serum of patients with fatty liver disease. Diabetes Res Clin Pract 2013;99(3):327-34.

59. Zhang ZC, Liu Y, Xiao LL, Li SF, Jiang JH, Zhao Y, et al. Upregulation of miR$125 \mathrm{~b}$ by estrogen protects against non-alcoholic fatty liver in female mice. J Hepatol 2015;63(6):1466-75.

60. Fisher K, Vuppalanchi R, Saxena R. Drug-induced liver injury. Arch Pathol Lab Med 2015;139(7):876-87.

61. Fukushima T, Hamada Y, Yamada H, Horii I. Changes of micro-RNA expression in rat liver treated by acetaminophen or carbon tetrachloride - regulating role of micro-RNA for RNA expression. J Toxicol Sci 2007;32(4):401-9.

62. Pogribny IP, Tryndyak VP, Boyko A, Rodriguez-Juarez R, Beland FA, Kovalchuk 0 . Induction of microRNAome deregulation in rat liver by long-term tamoxifen exposure. Mutat Res 2007;619(1-2):30-7.

63. Endo S, Yano A, Fukami T, Nakajima M, Yokoi T. Involvement of miRNAs in the early phase of halothane-induced liver injury. Toxicology 2014;319:75-84.

64. Wang K, Zhang S, Marzolf B, Troisch P, Brightman A, Hu Z, et al. Circulating microRNAs, potential biomarkers for drug-induced liver injury. Proc Natl Acad Sci U S A 2009;106(11):4402-7.

65. Yoshioka W, Higashiyama W, Tohyama C. Involvement of microRNAs in dioxin-induced liver damage in the mouse. Toxicol Sci 2011;122(2):457-65.

66. Strillacci A, Griffoni C, Sansone P, Paterini P, Piazzi G, Lazzarini G, et al. MiR-101 downregulation is involved in cyclooxygenase-2 overexpression in human colon cancer cells. Exp Cell Res 2009;315(8):1439-47.

67. Moffat ID, Boutros PC, Celius T, Lindén J, Pohjanvirta R, Okey AB. MicroRNAs in adult rodent liver are refractory to dioxin treatment. Toxicol Sci 2007;99(2):470-87.

68. Yang W, Lian J, Feng Y, Srinivas S, Guo Z, Zhong H, et al. Genome-wide miRNA-profiling of aflatoxin B1-induced hepatic injury using deep sequencing. Toxicol Lett 2014;226(2):140-9.

69. Malik AI, Williams A, Lemieux CL, White PA, Yauk CL. Hepatic mRNA, microRNA, and miR-34a-target responses in mice after 28 days exposure to doses of benzo(a)pyrene that elicit DNA damage and mutation. Environ Mol Mutagen 2012;53(1):10-21.

70. Padgett KA, Lan RY, Leung PC, Lleo A, Dawson K, Pfeiff J, et al. Primary biliary cirrhosis is associated with altered hepatic microRNA expression. J Autoimmun 2009;32(3-4):246-53.

71. Banales JM, Sáez E, Uriz M, Sarvide S, Urribarri AD, Splinter P, et al. Upregulation of microRNA 506 leads to decreased $\mathrm{Cl}$-/HCO3- anion exchanger 2 expression in biliary epithelium of patients with primary biliary cirrhosis. Hepatology 2012;56(2):687-97.

72. Tan Y, Pan T, Ye Y, Ge G, Chen L, Wen D, et al. Serum microRNAs as potential biomarkers of primary biliary cirrhosis. PLoS One 2014;9(10):e111424.

73. Migita K, Komori A, Kozuru H, Jiuchi Y, Nakamura M, Yasunami M, et al. Circulating microRNA profiles in patients with type-1 autoimmune hepatitis. PLoS One 2015;(11):e0136908.

74. Voigtländer T, Gupta SK, Thum S, Fendrich J, Manns MP, Lankisch TO, et al. MicroRNAs in serum and bile of patients with primary sclerosing cholangitis and/or cholangiocarcinoma. PLoS One 2015;10(10):e0139305.

75. Bernuzzi F, Marabita F, Lleo A, Carbone M, Mirolo M, Marzioni M, etal. Serum microRNAs as novel biomarkers for primary sclerosing cholangitis and cholangiocarcinoma. Clin Exp Immunol 2016;185(1):61-71. doi: 10.1111/cei.12776.

76. Li J, Fu H, Xu C, Tie Y, Xing R, Zhu J, et al. MiR-183 inhibits TGF-beta1induced apoptosis by downregulation of PDCD4 expression in human hepatocellular carcinoma cells. BMC Cancer 2010;10:354.

77. Liu C, Yu J, Yu S, Lavker RM, Cai L, Liu W, et al. MicroRNA-21 acts as an oncomir through multiple targets in human hepatocellular carcinoma. J Hepatol 2010;53(1):98-107.

78. Li N, Fu H, Tie Y, Hu Z, Kong W, Wu Y, et al. MiR-34a inhibits migration and invasion by down-regulation of c-Met expression in human hepatocellular carcinoma cells. Cancer Lett 2009;275(1):44-53.

79. Law PT, Ching AK, Chan AW, Wong QW, Wong CK, To KF, et al. MiR-145 modulates multiple components of the insulin-like growth factor pathway in hepatocellular carcinoma. Carcinogenesis 2012;33(6):1134-41. 
80. Zhang Y, Wei W, Cheng N, Wang K, Li B, Jiang X, et al. Hepatitis C virusinduced up-regulation of microRNA-155 promotes hepatocarcinogenesis by activating Wnt signaling. Hepatology 2012;56(5)1631-40. doi: 10.1002/hep.25849.

81. Wong QW, Ching AK, Chan AW, Choy KW, To KF, Lai PB, et al. MiR-222 overexpression confers cell migratory advantages in hepatocellular carcinoma through enhancing AKT signaling. Clin Cancer Res 2010;16(3):867-75.

82. Ding X, Ding J, Ning J, Yi F, Chen J, Zhao D, et al. Circulating microRNA-122 as a potential biomarker for liver injury. Mol Med Rep 2012;5(6):1428-32. doi: $10.3892 / \mathrm{mmr} .2012 .838$.

83. Cimmino A, Calin GA, Fabbri M, Iorio MV, Ferracin M, Shimizu M, et al MiR-15 and miR-16 induce apoptosis by targeting BCL2. Proc Natl Acad Sci U S A 2005;102(39):13944-9.

84. Wu CS, Yen CJ, Chou RH, Chen JN, Huang WC, Wu CY, et al. Downregulation of microRNA-15b by hepatitis B virus X enhances hepatocellular carcinoma proliferation via fucosyltransferase 2-induced Globo H expression. Int J Cancer 2014;134(7):1638-47.

85. Yan X, Liang H, Deng T, Zhu K, Zhang S, Wang N, et al. The identification of novel targets of miR-16 and characterization of their biological functions in cancer cells. Mol Cancer 2013;12:92.

86. Asangani I, Rasheed SA, Nikolova DA, Leupold JH, Colburn NH, Post S, et al. MicroRNA-21 (miR-21) post-transcriptionally downregulates tumor suppressor Pdcd4 and stimulates invasion, intravasation and metastasis in colorectal cancer. Oncogene 2008;27(15):2128-36.

87. Zhu S, Si ML, Wu H, Mo YY. MicroRNA-21 targets the tumor suppressor gene tropomyosin 1 (TPM1). J Biol Chem 2007;282(19):14328-36.

88. Connolly EC, van Doorslaer K, Rogler LE, Rogler CE. Overexpression of miR-21 promotes an in vitro metastatic phenotype by targeting the tumor suppressor RHOB. Mol Cancer Res 2010;8(5):691-700.

89. Lal A, Navarro F, Maher CA, Maliszewski LE, Yan N, O’Day E, et al. MiR-24 Inhibits cell proliferation by targeting E2F2, MYC, and other cell-cycle genes via binding to "seedless" 3'UTR microRNA recognition elements. Mol Cell 2009;35(5):610-25.

90. Qin W, Shi Y, Zhao B, Yao C, Jin L, Ma J, et al. MiR-24 regulates apoptosis by targeting the open reading frame (ORF) region of FAF1 in cancer cells. PLoS One 2010;5(2):e9429.

91. Wang T, Xu Z. MiR-27 promotes osteoblast differentiation by modulating Wnt signaling. Biochem Biophys Res Commun 2010;402(2):186-9.

92. Pekarsky Y, Santanam U, Cimmino A, Palamarchuk A, Efanov A, Maximov $\mathrm{V}$, et al. Tcl1 expression in chronic lymphocy tic leukemia is regulated by miR-29 and miR-181. Cancer Res 2006;66(24):11590-3.

93. Steele R, Mott JL, Ray RB. MBP-1 upregulates miR-29b that represses Mcl-1, collagens, and matrix-metalloproteinase-2 in prostate cancer cells. Genes Cancer 2010;1(4):381-7.

94. Sun F, Fu H, Liu Q, Tie Y, Zhu J, Xing R, et al. Downregulation of CCND1 and CDK6 by miR-34a induces cell cycle arrest. FEBS Lett 2008;582(10):1564-8.

95. Ding J, Li M, Wan X, Jin X, Chen S, Yu C, et al. Effect of miR-34a in regulating steatosis by targeting PPAR $\alpha$ expression in nonalcoholic fatty liver disease. Sci Rep 2015;5:13729. doi: 10.1038/srep13729.

96. Niu H, Wang K, Zhang A, Yang S, Song Z, Wang W, et al. MiR-92a is a critical regulator of the apoptosis pathway in glioblastoma with inverse expression of BCL2L11. Oncol Rep 2012;28(5):1771-7.

97. Chen ZL, Zhao XH, Wang JW, Li BZ, Wang Z, Sun J, et al. MicroRNA-92a promotes lymph node metastasis of human esophageal squamous cell carcinoma via E-cadherin. J Biol Chem 2011;286(12):10725-34.

98. Yan D, Ng WL, Zhang X, Wang P, Zhang Z, Mo YY, et al. Targeting DNAPKcs and ATM with miR-101 sensitizes tumors to radiation. PLoS One 2010;5(7):e11397.

99. Wei X, Tang C, Lu X, Liu R, Zhou M, He D, et al. MiR-101 targets DUSP1 to regulate the TGF- $\beta$ secretion in sorafenib inhibits macrophage-induced growth of hepatocarcinoma. Oncotarget 2015;6(21):18389-405.

100. Lin CJ, Gong HY, Tseng HC, Wang WL, Wu JL. miR-122 targets an antiapoptotic gene, Bcl-w, in human hepatocellular carcinoma cell lines. Biochem Biophys Res Commun 2008;375(3):315-20. doi: 10.1016/j.bbrc. 2008.07.

101. Gramantieri L, Ferracin M, Fornari F, Veronese A, Sabbioni S, Liu CG, et al Cyclin G1 is a target of miR-122a, a microRNA frequently down-regulated in human hepatocellular carcinoma. Cancer Res 2007;67(13):6092-9.

102. Xu H, He JH, Xiao ZD, Zhang QQ, Chen YQ, Zhou H, et al. Liver-enriched transcription factors regulate microRNA-122 that targets CUTL1 during liver development. Hepatology 2010;52(4):1431-42
103. Li J, Ghazwani M, Zhang Y, Lu J, Li J, Fan J, et al. MiR-122 regulates collagen production via targeting hepatic stellate cells and suppressing P4HA1 expression. J Hepatol 2013;58(3):522-8.

104. Wang HQ, Yu XD, Liu ZH, Cheng X, Samartzis D, Jia LT, et al. Deregulated miR-155 promotes Fas-mediated apoptosis in human intervertebral disc degeneration by targeting FADD and caspase-3. J Pathol 2011;225(2):23242. doi: 10.1002 /path.2931.

105. Zhu D, Xie H, Li H, Cai P, Zhu H, Xu C, et al. Nidogen-1 is a common target of microRNAs MiR-192/215 in the pathogenesis of Hirschsprung's disease. J Neurochem 2015;134(1):39-46. doi: 10.1111/jnc.13118.

106. Lian J, Jing Y, Dong Q, Huan L, Chen D, Bao C, et al. MiR-192, a prognostic indicator, targets the SLC39A6/SNAIL pathway to reduce tumor metastasis in human hepatocellular carcinoma. Oncotarget 2016;7(3): 2672-83.

107. Pichiorri F, Suh SS, Rocci A, De Luca L, Taccioli C, Santhanam R, et al. Downregulation of p53-inducible microRNAs 192, 194, and 215 impairs the p53/MDM2 autoregulatory loop in multiple myeloma development. Cancer Cell 2010;18(4):367-81.

108. Zhang Y, Fan KJ, Sun Q, Chen AZ, Shen WL, Zhao ZH, et al. Functional screening for miRNAs targeting Smad4 identified miR-199a as a negative regulator of TGF- $\beta$ signalling pathway. Nucleic Acids Res 2012;40(18):9286-97.

109. Shatseva T, Lee DY, Deng Z, Yang BB. MicroRNA miR-199a-3p regulates cell proliferation and survival by targeting caveolin-2. J Cell Sci 2011;124:2826-36.

110. Han Y, Kuang Y, Xue X, Guo X, Li P, Wang X, et al. NLK, a novel target of miR199a-3p, functions as a tumor suppressor in colorectal cancer. Biomed Pharmacother 2014;68(5):497-505.

111. Schickel R, Park SM, Murmann AE, Peter ME. MiR-200c regulates induction of apoptosis through CD95 by targeting FAP-1. Mol Cell 2010;38(6):908-15.

112. Nie J, Liu L, Zheng W, Chen L, Wu X, Xu Y, et al. microRNA-365, downregulated in colon cancer, inhibits cell cycle progression and promotes apoptosis of colon cancer cells by probably targeting Cyclin D1 and Bcl-2. Carcinogenesis 2012:33(1):220-5. doi: 10.1093/carcin/bgr245.

113. Guo SL, Ye H, Teng Y, Wang YL, Yang G, Li XB, et al. Akt-p53-miR-365-cyclin D1/cdc25A axis contributes to gastric tumorigenesis induced by PTEN deficiency. Nat Commun 2013;4:2544. doi: 10.1038/ncomms3544.

114. Zhang J, Bian Z, Zhou J, Song M, Liu Z, Feng Y, et al. MicroRNA-638 inhibits cell proliferation by targeting phospholipase D1 in human gastric carcinoma. Protein Cell 2015;6(9):680-8. doi: 10.1007/s13238-015-0187-8.

115. Tay Y, Tan SM, Karreth FA, Lieberman J, Pandolfi PP. Characterization of dual PTEN and p53-targeting microRNAs identifies microRNA-638/Dnm2 as a two-hit oncogenic locus. Cell Rep 2014;8(3):714-22. doi: 10.1016/j. celrep.2014.06.064.

116. Xie KL, Zhang YG, Liu J, Zeng Y, Wu H. MicroRNAs associated with HBV infection and HBV-related HCC. Theranostics 2014;4(12):1176-92. doi: $10.7150 /$ thno.8715.

117. Enache LS, Enache EL, Ramière C, Diaz O, Bancu L, Sin A, et al. Circulating RNA molecules as biomarkers in liver disease. Int J Mol Sci 2014;15(10):17644-66. doi: 10.3390/ijms151017644.

118. Liu X, Wang T, Wakita T, Yang W. Systematic identification of microRNA and messenger RNA profiles in hepatitis $\mathrm{C}$ virus-infected human hepatoma cells. Virology 2010;398(1):57-67.

119. Jiang M, Broering R, Trippler M, Wu J, Zhang E, Zhang X, et al. MicroRNA-155 controls Toll-like receptor 3- and hepatitis C virus-induced immune responses in the liver. J Viral Hepat 2014;21(2):99-110.

120. Shrivastava S, Mukherjee A, Ray RB. Hepatitis C virus infection, microRNA and liver disease progression. World J Hepatol 2013;5(9):479-86. doi: 10.4254/wjh.v5.i9.479.

121. Bala S, Szabo G. MicroRNA signature in alcoholic liver disease. Int J Hepatol 2012;2012:498232. doi: 10.1155/2012/498232.

122. McDaniel K, Herrera L, Zhou T, Francis H, Han Y, Levine P, et al. The functional role of microRNAs in alcoholic liver injury. J Cell Mol Med 2014;18(2):197-207.

123. Chen YP, Jin X, Xiang Z, Chen SH, Li YM. Circulating MicroRNAs as potential biomarkers for alcoholic steatohepatitis. Liver Int 2013;33(8):1257-65.

124. Bala S, Petrasek J, Mundkur S, Catalano D, Levin I, Ward J, et al. Circulating microRNAs in exosomes indicate hepatocyte injury and inflammation in alcoholic, drug-induced, and inflammatory liver diseases. Hepatology 2012;56(5):1946-57.

125. Szabo G, Csak T. Role of microRNAs in NAFLD/NASH. Dig Dis Sci 2016;61(5):1314-24. doi: 10.1007/s10620-015-4002-4. 
126. Sobolewski C, Calo N, Portius D, Foti M. MicroRNAs in fatty liver disease. Semin Liver Dis 2015;35(1):12-25.

127. Gerhard GS, DiStefano JK. Micro RNAs in the development of non-alcoholic fatty liver disease. World J Hepatol 2015;7(2):226-34

128. Tryndyak VP, Latendresse JR, Montgomery B, Ross SA, Beland FA, Rusyn I, et al. Plasma microRNAs are sensitive indicators of inter-strain differences in the severity of liver injury induced in mice by a choline- and folate-deficient diet. Toxicol Appl Pharmacol 2012;262(1):52-9.

129. Wang Y, Chen T, Tong W. miRNAs and their application in drug-induced liver injury. Biomark Med 2014;8(2):161-72. doi: 10.2217/bmm.13.147.

130.Yan S, Wang J, Zhang W, Dai J. Circulating microRNA profiles altered in mice after $28 \mathrm{~d}$ exposure to perfluorooctanoic acid. Toxicol Lett 2014;224(1):24-31.

131. Laterza OF, Lim L, Garrett-Engele PW, Vlasakova K, Muniappa N, Tanaka WK, et al. Plasma MicroRNAs as sensitive and specific biomarkers of tissue injury. Clin Chem 2009;55(11):1977-83. doi: 10.1373/ clinchem.2009.131797.

132. Wang J, Zhang Y, Zhang W, Jin Y, Dai J. Association of perfluorooctanoic acid with HDL cholesterol and circulating miR-26b and miR-199-3p in workers of a fluorochemical plant and nearby residents. Environ Sci Technol 2012;46(17):9274-81.

133. Mizuguchi Y, Takizawa T, Yoshida H, Uchida E. Dysregulated microRNAs in progression of hepatocellular carcinoma: A systematic review. Hepatol Res 2016;46(5):391-406. doi: 10.1111/hepr.12606.

134. Kota J, Chivukula RR, O’Donnell KA, Wentzel EA, Montgomery CL, Hwang HW, et al. Therapeutic microRNA delivery suppresses tumorigenesis in a murine liver cancer model. Cell 2009;137(6):1005-17.
135. Wang C, Ren R, Hu H, Tan C, Han M, Wang X, et al. MiR-182 is up-regulated and targeting Cebpa in hepatocellular carcinoma. Chin J Cancer Res 2014;26(1):17-29. doi: 10.3978/j.issn.1000-9604.2014.01.01.

136. Chang-Hao Tsao S, Behren A, Cebon J, Christophi C. The role of circulating microRNA in hepatocellular carcinoma. Front Biosci (Landmark Ed) 2015;20:78-104.

137. Wang X, Zhang J, Zhou L, Lu P, Zheng ZG, Sun W, et al. Significance of serum microRNA-21 in diagnosis of hepatocellular carcinoma (HCC): clinical analyses of patients and an HCC rat model. Int J Clin Exp Pathol 2015;8(2):1466-78.

\section{KOMENTARZ}

Artykuł stanowi przegląd wiedzy nt. roli miRNA w patologii wątroby. Czas pokaże, czy znajdzie to szersze zastosowanie w diagnostyce, a zwłaszcza w terapii, ale obecnie wydaje się to atrakcyjną opcją, głównie w odniesieniu do raka w komórkach wątroby czy dróg żółciowych oraz przewlekłego zakażenia HBV, nieuleczalnego na obecnym etapie wiedzy. Artykuł może być inspiracją dla badaczy.

prof. dr hab. n. med. Marta Wawrzynowicz-Syczewska 